
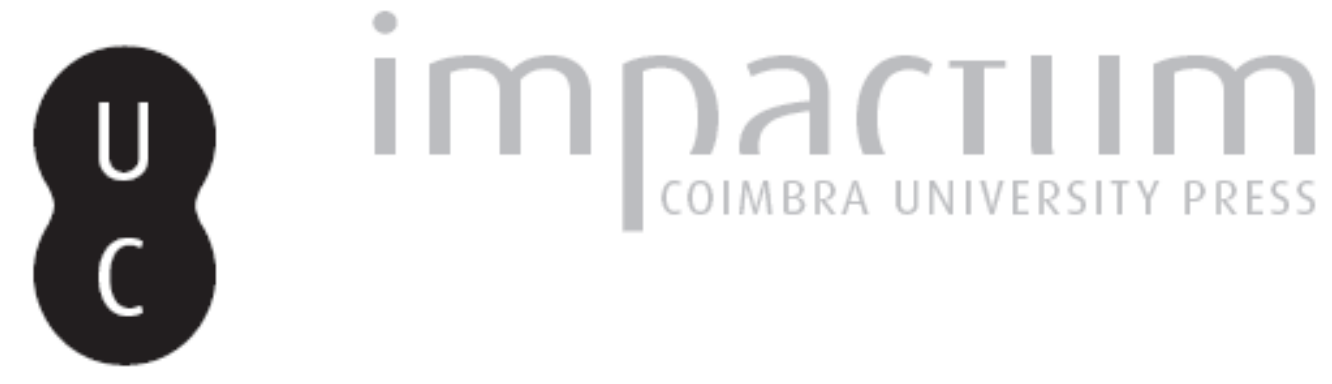

\title{
Toponyms of Lusitania: a re-assessment of their origins
}

Autor(es): $\quad$ Curchin, Leonard A.

Publicado por: Faculdade de Letras da Universidade de Coimbra

URL persistente:

URI:http://hdl.handle.net/10316.2/37749

DOI:

DOI:http://dx.doi.org/10.14195/1647-8657_46_7

Accessed : $\quad$ 26-Apr-2023 09:10:09

A navegação consulta e descarregamento dos títulos inseridos nas Bibliotecas Digitais UC Digitalis, UC Pombalina e UC Impactum, pressupõem a aceitação plena e sem reservas dos Termos e Condições de Uso destas Bibliotecas Digitais, disponíveis em https://digitalis.uc.pt/pt-pt/termos.

Conforme exposto nos referidos Termos e Condições de Uso, o descarregamento de títulos de acesso restrito requer uma licença válida de autorização devendo o utilizador aceder ao(s) documento(s) a partir de um endereço de IP da instituição detentora da supramencionada licença.

Ao utilizador é apenas permitido o descarregamento para uso pessoal, pelo que o emprego do(s) título(s) descarregado(s) para outro fim, designadamente comercial, carece de autorização do respetivo autor ou editor da obra.

Na medida em que todas as obras da UC Digitalis se encontram protegidas pelo Código do Direito de Autor e Direitos Conexos e demais legislação aplicável, toda a cópia, parcial ou total, deste documento, nos casos em que é legalmente admitida, deverá conter ou fazer-se acompanhar por este aviso.

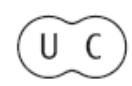




\section{CONIMBRIGA}

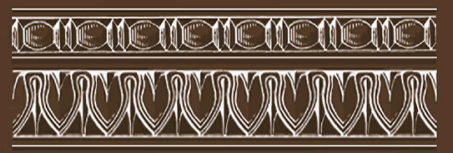

INSTITUTO DE ARQUEOLOGIA

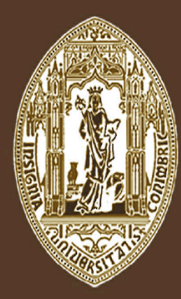

VOLUME XLVI - 2007

FACULDADE DE LETRAS UNIVERSIDADE DE COIMBRA 
LEONARD A. CURChIN

Classical Studies. University of Waterloo (Canada)

TOPONYMS OF LUSITANIA: A RE-ASSESSMENT OF THEIR ORIGINS "Conimbriga" XLVI (2007) p. 129-160

ABSTRACT: Recent advances in linguistic theory and methodology have given greater scientific validity to the study of ancient toponyms. This article re-examines the origin of the various place-names of the Roman province of Lusitania, rejecting some proposed etymologies while offering several new or modified ones. The paper concludes with a tabulation of the proportion of Indo-European, Celtic, Latin, and other roots in the toponyms of the province.

RESUMEN: Avances recientes en teoría lingüística y en metodología han dado más validez científica al estudio de la toponimia antigua. En este artículo se examina de nuevo el origen de los topónimos de la provincia romana de Lusitania, tanto rechazando unas etimologías anteriores como ofreciendo algunas nuevas o modificadas. Para terminar, se comparan las proporciones de radicales indo-europeos, célticos, latinos, y otros en la toponimia de la provincia. 
(Página deixada propositadamente em branco) 


\section{TOPONYMS OF LUSITANIA: A RE-ASSESSMENT OF THEIR ORIGINS}

\section{Introduction}

Ancient Lusitania not only experienced several successive influxes of inhabitants and languages - Pre-Indo European, Indo-European, Celtic, Iberian, Greek and Roman - but preserved them for posterity in its repertory of place-names. These toponyms may be formed from personal, ethnic or divine names, from hydronyms, or from common nouns. They serve as a valuable fossil record of the various linguistic layers associated with the region's cultural history ${ }^{1}$.

While the presence of different languages in Lusitania has long been recognized, early attempts to identify the etymology of specific toponyms were plagued by false assumptions or flights of fancy (CURCHIN forthcoming). For instance, W. vON HuMBOLDT $(1821$; 1879) proposed that several town-names - Aritium Vetus, Burdua, Lavara, Montobrica, Moron, Serpa, Talabara and Talori - were related to Basque words. Subsequent investigators (SCHULTEN 1931: 784; BERTOLDI 1953; GARVEns 1964) claimed a Basque connection for Arandis, Balsa, Mendiculeia, Obila and Verurium. Meanwhile, Schulten (1930; 1955) asserted an Etruscan origin for Achale, Agonis, Mons Herminius and Moron, based on a supposed similarity to Etruscan words. Names of possibly Indo-European yet non-Celtic etymology were supposed to represent a Ligurian or Illyrian layer. Thus Aravi, Langobriga and Vipasca were identified as Ligurian (SCHMOLL 1959: 109; AlbuQUERQUE 1962: 207; MENÉndeZ PIDAL 1968: 162-63), while Baedorus, Bletisama, Conistorgis, Eburobrittium, Lama and Salmantica were considered Illyrian (Tovar 1957; LomAs 1980: 59-60). Nowadays scholars

1 This project has been funded by a grant from the Social Sciences and Humanities Research Council of Canada. 
tend to avoid these misleading "Ligurian" and "Illyrian" labels, preferring to follow KRAHE (1962) in designating the early linguistic substratum with Indo-European (but non-Celtic) characteristics as "Old European" (Alteuropäisch). However, some of the toponyms identified by Krahe as Alteuropäisch are of debatable Indo-European origin, or are shared by a range of non-Indo-European languages extending from the Atlantic to Anatolia (Moralejo Álvarez 2001: 503).

More recently, GUERRA (1998) has studied the toponyms of Lusitania and Galicia, while GARcía AlONSO (2003) has revisited the Hispanic place-names in Ptolemy's Geographia 2 . For the most part they summarize the opinions of previous scholars, though sometimes offering suggestions of their own. A very different contribution has been made by VILLAR (1995a; 2002) who proposes that several toponymic roots previously considered Iberian, are in fact remnants of the Old European language: for instance, $u b a$ would come from Indo-European $* a b / a p-$, ur from Indo-European $* a^{u} e r-$, and so on. However, some of Villar's proposals are less convincing than others, and his views have not met with universal acceptance.

The present article consists of a discussion of Lusitanian toponyms, arranged alphabetically, followed by conclusions. Location of these names, where known, is indicated on the map (Est. I). Note the following abbreviations: $\mathrm{PN}=$ personal name. $\mathrm{DN}=$ divine name. $\mathrm{EN}=$ ethnic or tribal name. GN = geographical name. IE = Indo-European.

\section{Catalogue of Toponyms}

Abelterion/Apeilokarion - The itineraries read Abel-; the Apeilspelling is probably a hellenized rendering. Although *ab-/ap- exists as an IE hydronym, a likelier root is Celtic abel- from IE *apelo "strength", seen in the PNs Abelio/Abellius (HoLDER 1896-1907, vol. I: 6 ) and the Celtiberian gentilic abilikum. The element -ter-forms IE nouns of agent (MEILLET 1969: 272).

Abila/Obila - According to VILLAR (2000: 370), the sound of indigenous "a" was interpreted by the Romans as either "o" or "a", hence the variant spellings. There is no reason not to associate Ptolemy's

2 My sincere thanks to Dr. Guerra for providing me with a copy of his dissertation. 
Obila with modern Avila, birthplace of Priscillian, attested as Abila by Hieronymus (De viris illus., 121) and as *Avila in the epitaph of an Avile(nsis) at Nava de Ricomalillo, Toledo (HEp., 4, 890). There is an Obilonna among the Allobroges of Narbonensis. The likeliest root is the IE hydronym *ab-, cf. Old Gaelic $a b h$, Welsh $a w$ "water, river".

Achale insula - Since Avienus specifies that this is an indigenous name ("vocata ab incolis": Ora maritima, 184), claims for a Phoenician or Greek origin are misguided (HÜBNER 1893: 222; BANDEIRA FERREIRA 1959). Cf. the Old Irish GN Achall (HogAN 1910: 4).

Ad Lippos - Although VILLAR (1999: 704) considers this the northernmost example of a GN in -ippo, the preposition $a d$ suggests a Latin phrase. This road station may be named for an inn "Ad lippos", meaning "at (the place of) the bleary-eyed ones", perhaps a reference to tipsy customers.

Ad Septem Aras - A Latin name, paralleled by GNs Ad Aras in Baetica and in south-eastern Tarraconensis. This mansio stood next to seven altars, perhaps prehistoric dolmens as VASCONCELLOS (1938: 42ff.) suggested.

Ad Sorores - This station could be named for an inn operated by sisters, or an inn sign depicting mythological sisters, or a rock formation known as the Sisters.

Adrum flumen - The name comes from the IE hydronym *ad-ro"watercourse" (POKORNY 1959: 4). Parallels include the river Adrus in Lugdunensis, and the town Adrobrica in Galicia.

Aebosocula - A diminutive form of an EN Aebosoci, not otherwise recorded in Lusitania but attested twice in Galicia (CIL, II, 2477, 2527).

Aeminium - Possibly founded in the Early Empire (Alarcão 1988: 25) and thus perhaps from a rare Latin PN Aeminius (Eminius: CIL, V, 7943; Aeminia: CIL, VI, 11174). However, since the first of these examples comes from the Maritime Alps, it may be Celtic rather than Latin. Pliny $(N H, 4.115)$ lists Aeminius as another name for the river Limia in Galicia; GUERRA (1996: 151) thinks it may be a doublet of Minius. The existence of a harbour Aemines in Narbonensis (Itin. marit., 506) further supports the possibility of a Celtic root*aimin-, possibly from IE *ai- "to allot". 
Agonis insula - Though of Greek appearance, this name could be Celtic, cf. the GN Agodano in the Alps.

Alantune - This name is paralleled by the town Alantone in the Ebro valley. Both come from IE *alant- from *al- "to flow" (VILLAR \& PRÓSPER 2005: 433).

Ammaia - IE *amma "mother" might suggest that this is a tribal "metropolis". But it could equally be derived from the PN Ammaia, attested (only in the feminine) in Lusitania (GRUPO MÉRIDA 2003: 85). A GN Amaia is recorded in Cantabria.

Ana flumen - That the correct name is Ana rather than Anas is argued by SÁEZ FERNÁNDEZ (1994: 106-7). Though regarded as Iberian by early scholars, an IE origin is suggested by numerous Ana- GNs in western Europe (VILLAR 2000: 329-30).

Apiobica - see Iapiobica.

Aquabona - see Equabona.

Arabriga - The Celtic ending -briga (from *brig- "high, strong") regularly designates hill-forts in Iberia. However, Celtic are- "near, in front of" (from IE * $p^{o} r i$-) does not fit here, as the town would be a hillfort, not "near" it (though GARCíA ALONSO 2006 ingeniously suggests "the fort at the front"). Alternatively, Celtic *ara "field" (from IE *ar(e)-, whence Old Irish ár "cultivated field", Welsh âr "ploughed land", would yield a meaning "the fort of the fields" (GARCía AlONSO 2006). IE *ar- "outside, open", whence Latin area, would also be appropriate to an open-air site.

Araducta - Closely paralleled by Araducca in Galicia. For ar(e)see Arabriga; but -duct- has never been adequately explained.

Arandis - The etymology *are-randa "next to the border" (COROMINAS 1972: 83) is conceivable, as is the IE hydronym *ar-, but Welsh aran "peaked hill" (JOHNSTON 1934: 89) suggests a more satisfying meaning. Celtic parallels include Arandatum, Arandisni and Arandunici (HoLDER 1896-1907, vol. I: 172). An alternative origin is the PN Aranta or DN Arantius, both attested in Lusitania.

Araocel(um) - Possibly from an Old European hydronym *ar-av(BASCUAS 2002: 34, cf. Arausio in Gaul) plus ocelo- (see Ocelum). But it could equally be Celtic *are-ocelo- "near the promontory". 
Aravi - From the Old European hydronym *ar-av- (see Araocelum).

Arbua - Attested by mention of an Arbuensis (HEp., 1, 698), this name recalls Arbocala of the Vaccaei (Polybius 3, 14,1; Livy 21, 5,6). Cf. Lat. arbor, from IE *er(e)dh- "high".

Arcobriga - Paralleled by a homonym in Celtiberia, this name most likely comes from the DN Arco (CURCHIN 1997: 260), perhaps ultimately from a Celtic root *arc- "to defend" (Moralejo Álvarez 2005: 224) plus -briga "fortress". However, the frequent GNs Arco in modern Portugal may be named for memorial arches (MARQUES 1984: 108).

Arcuce - GUERRA (1998: 294) reasonably suggests that the name of this castellum comes from the same root as Arcobriga. On the interchange of $o / u$, see below on Monda/Munda. But ar- could equally represent Celtic *are- (see Arabriga). On -cuc- perhaps cf. the Vaccaean GN Cougion. Possible parallels are provided by the GNs Arcunia/ /Hercynia in Germany (HolDER 1896-1907, vol. I: 184) and Arcunes in Thrace (Procopius, De aedificiis, 4,4,3).

Areva flumen - From the IE hydronym *ar- (Hoz 1963: 233).

Aritium - Probably Celtic, as suggested by Gaulish *aritisia "slate" (LAMBERT 1995: 187) and the Gaulish PN Aritus.

Augustobriga - An obvious hybrid of Latin Augustus and Celtic -briga.

Baedorus - Although TOVAR (1957: 279) would relate this name to the Illyrian PN Baedarus, VILLAR (2000: 239-46) points to numerous Hispanic GNs in bai-, which he derives from IE $* g^{w} h e i-$. Close parallels include Baedro (Baetica) and Bedunia (Asturias).

Baesuri - The name, attested on coins as well as the itineraries, is one of numerous names in *bait-/bais- in the south of the Peninsula (VILlar 1999: 689). Compare also a GN Baeserta in the Pyrenees (HOLDER 1896-1907, vol. I: 327).

Balatucelum - Numerous Hispano-Celtic names in bal-, as well as ocelo- (see Ocelum) provide the etymology of this toponym. Cf. particularly the gentilic name Balatuscun ( $A E, 1987,616 \mathrm{f})$. 
Balsa - Though Tovar (1970: 7-9) considers Balsa a Basque loanword into Indo-European, found as far east as Lithuania, Bal-names are frequent in both Iberian and Celtic. The GN Balsio is attested in the Ebro valley. According to VILLAR (1999: 690-91), the spelling Balsilipa for Basilipo (Rav., 316, 13) could preserve an indigenous form *bals-ilipo from the same root as Balsa.

Baniensis civitas - Paralleled by Baniana in Baetica. Plausibly Celtic, since Baniacus is conjectured as the origin of five French GNs Bagnac/Bagny (HoLDER 1896-1907, vol. III: 799). A likely root is suggested by Old Irish bán "white", Sanskrit bhânù "idem" from IE *bha-, Celtic *bane- "to shine".

Barbarium promontorium - Compare the Baetican GNs Barbariana, Barbesula and Singili Barba, possibly from IE *barb- "water" (Hoz 1963: 234).

Bletisa(ma) - This is a Celtic superlative, cf. Segisama, Uxama, Belisama (Britain). The probable root is IE *plet- "flat".

Braetolaeum - Despite the existence of a PN Braetius (not attested in Lusitania), the root may be IE *brito-lag-yo, with lenition of /g/ (VILLAR \& PRÓSPER 2005: 267).

Burdua - Perhaps related to the Celtic PN Burdo (AcS I col. 638-39). Other possible parallels include Burdoga in Baetica, Burdigala in Gaul (though Whatmough 1970: 400 would relate this to Aquitanian burdus "mule"), Burdomina and Burdopes on the Danube (Procopius, De aedif., 284,21 and 53) and the Celtiberian mint burzau, where $z$ represents /dh/. The probable root is IE *bhou- "to grow", whence Welsh bwr "big, strong", Aquitanian *bur "height" (DAUZAT \& RostAing 1963: 125).

Burrulobriga - On briga, see Arabriga. Burrulo-, variant Burrilo-is a diminutive of PN Burrus, from Celtic *burro- "stout, big", ultimately from IE *bhou- (see Burdua). Both Burrus and Burrilus are attested in Lusitania (GRUPO MÉRIDA 2003: 120)

Caeciliana - Named for a Caecilius family. Possibly refers to a camp of Q. Caecilius Metellus Pius (Alarcão 2004: 320), cf. Castra Caecilia.

Caeilobrigoi - The ending -brigoi clearly denotes "the inhabitants of the hill-fort". Caeilo- appears to derive from IE *kailo- "well-ome- 
ned, safe", with reference to the protectiveness of the site. Comparable are the gentilics Caelaon and Caelicum (VILLAR \& PedRERo 2001: 691), also the Caelis river (Britain). An alternative possibility is suggested by Old Irish cael "a stream flowing through a marsh; a narrow neck of a lake" (HoGAN 1910: 135).

Caelioni(c)oi - From the same root as Caeilobrigoi.

Caepiana - Although GarCíA Alonso (2003: 96) suggests that this GN is named after a possessor named Caepius, Ptolemy lists it as a city, not a villa. Since it lies too far west to be associated with Servilius Caepio who campaigned against Viriathus (ALARCÃO 2004: 322), it is probably named after his homonymous son, who conquered the Lusitani in 109-107 B.C. (GUERRA 2004: 222-224).

Caesarobriga - A Latin-Celtic hybrid.

Caetobriga - Like the Gaulish GN Caetobrix, this name is clearly derived from Celtic *caito- "woods, meadow".

Cairieses - Although RIVET \& SMITH (1979: 286) derive British Caerini from Celtic *caero- "sheep", Cairieses may rather refer to a foundation by Caerius, a PN attested in Lusitania (GRUPO MÉRIDA 2003: 126)

Caliabriga - Rather than IE *kel- "dark" (VILLAR 2000: 314-17), this GN probably comes from the root *kal- "stone", considered pre-IE by RostaING (1958: 27) but possibly derived from IE *kal- "hard". Therefore, "rocky fortress". Cf. Calubriga (Asturias: CIL, II, 2610) and Caledonia in Britain.

Callipous flumen - It is unclear whether Ptolemy has translated an indigenous name into Greek ("beautiful foot"?) or simply transliterated it. It could consist of kal- (see Caliabriga) plus -ipo (SCHULTEN 1955: 341), though -ipo normally designates a city.

Calontenses - The infix -nt- indicates an IE name (Tovar 1958). Cal- could mean "stone" (see Caliabriga), though IE *kal- "dry" and *kel-/kal- "dark" are also possible. A Celtiberian PN Kalos ("black"?) is attested in Botorrita Bronze III $(1,44)$.

Caluri - Another cal- name, for which several possibilities are given under Caliabriga and Calontenses. There might be a connection 
with the PN Calus, attested four times in Lusitania (GRUPO MÉRIDA 2003: 129).

Camalocenses - Clearly associated with the common PN Camalus, cognate with the name of the Gaulish war-god Camulus, from IE *kem(e)- "to struggle".

Capara/Capera A derivation from Celtic *capro- "goat" (CERRILLO 1993: 151) seems more likely than IE *kapo- "place inundated by water" (GARCÍA Alonso 2003: 123), in view of Capara's location in Extremadura, dry sheep-ranching country. Cf. Capraria, one of the six Balearic islands according to Pliny $(\mathrm{NH}, 3,5,76)$.

Capsiana - Apart from a resemblance to Capsa in Africa (modern Gafsa), this GN remains unexplained.

Castra Caecilia - On the site of a camp of Q. Caecilius Metellus Pius, proconsul in Hispania Ulterior in 79 BC (SCHULTEN 1937: 173-74). From the ablative Castris comes the modern GN Cáceres (TovaR 1976: 236).

Castra Servilia - Named for a camp of Q. Servilius Caepio, who fought Sertorius (SCHULTEN 1937: 173-74).

Castrum Colubri - "castle of the serpent" (AlBAIGÈs 1998: 37), from Latin coluber "snake". Its modern name, Alange, is the Arabic translation (al-hanash) of the Latin coluber. Cf. Colubraria, the Latin translation of Ophiusa (referring to snakes) in the Baleares.

Cauliniana - Probably from the Latin gentilic name Caulius. In Gaul, *Cauliacum is the presumed etymon of the GNs Chaulhac (Lozère), Choilley (Haute-Marne) and Chouilly (Marne) (HoLder 1896-1907, vol. I: 867).

Caurium - Attempts to derive this from IE *koryos "troop, army" (RUbÉn JimÉnez 2004: 156) or *-uro- "river" (VILlAR \& PRÓSPER 2005 : $34)$ are unconvincing. A more satisfactory root is pre-IE $* \operatorname{kar}(r)$ "stone", whence Gaelic càrr "rock", Welsh caer "fortress". The PN Caurus, attested in eastern Lusitania (HEp., 3, 23) is possibly related, as are the GNs Caura/Cauria/Cauro, found in Baetica, northern Italy and Corsica.

Celticoflavi(um) - Attested in two inscriptions mentioning "Celticoflavienses" (CIL, II, 880; AE, 1996, 890). The name appears to sug- 
gest a Celtic town granted municipal privilege by the Flavians, cf. Flaviobriga (Varduli), Flavia Lambris (Galicia).

Centum Cellae - Purely Latin, with possible reference to a village of one-room huts.

Cenum - The name is Celtic, either from *cuenno- "head" whence Old Irish cenn, Welsh pen; or from *ceno- "remote", from the IE demonstrative *ko-, ke-, seen in Gaulish ENs Cenomani, Cenimagni (HOLDER 1896-1907, vol. I: 982)

Chretina - Ptolemy's toponym appears corrupt. If it should be read Cretina, we might compare the PN Cretius (CIL, II, 1942).

Cilibe - Mention of a city Kilibe in the new Artemidorus papyrus (KRAMER 2005: 27) confirms the reading Cilibitani (rather than Cibilitani) in Pliny. It should be equated with the mint Cilpes in the Algarve.

Cinginnia - Gaulish PNs Cingetorix and Cingenius, and Old Irish cing "champion, hero" come, via Celtic *cingo- "to step", from IE *ghengh- "to stride" (EvANS 1967: 177-79). Cinginnia might therefore mean "champion city" or "city of heroes". However, a likelier solution is to see cing- as a Lusitanian cognate of Latin cingo from IE *kenk- "to gird", referring to an enclosed area.

Cobelcorum civitas - Perhaps contracted from $c o(m) b$-, cf. kombalkores on Botorrita Bronze I. On belc-, cf. the Celtiberian GNs Belgida, Belcilesis (Ephemeris Epigraphica, VIII, 183, Segobriga). This name could therefore be Celtic.

Coerenses - Like the Coerob(rigenses) attested in Toledo province, this name is probably derived from IE *koiro- "dark, brown" (PRÓSPER 2004: 183-85).

Colarni - Also spelled Cularni (AlARCÃo 2004: 337). The nearest parallels are the Coelerni in Galicia (perhaps from IE *koilo- "thin") and the GN Colania in Britain. Colarni and Colania probably both come from IE *kel- "to tower; high", whence Latin collis "hill".

Collippo - The suffix -ippo "city", traditionally regarded as Iberian, though related by VILLAR (2000: 114-118) to Tartessos and thus possibly to Asia Minor, is here preceded by Celtic coll "hazel tree". The use of tree names is paralleled at Ebora and Fraxinum, below. 
Concordia - Clearly Latin, meaning "union, harmony".

Conimbriga/Coniumbriga - Spelled Coniumbriga by Pliny ( $\mathrm{NH}$, 4.113) and in inscriptions (CIL, II, 432, 5866), though the first of these, found at Freixo do Numão and dedicated to the gods of the Coniumbricenses, may be evidence for another Coniumbriga on the Douro. If Conimbriga is an abridged form of ${ }^{*}$ Coniombriga, it should mean "hill-fort of the Conii" (BLONDIN 1977). However, the Conii were a people of the Algarve, and there are no grounds (other than the toponym itself) for postulating that their territory once extended into northern Lusitania. But the element *conio- also appears in British GNs (Ariconium, Voroconium), perhaps from IE *konio- "common" (Greek koinos). Conimbriga could therefore mean "hill-fort of the common people". BúA (1999: 322) and Moralejo Álvarez (2003: 192) take a different approach, parsing the name as *konio-mbrig-, from *mbrig"field" (Gaulish brogae "idem", Old Irish mruig "country", brí "plain"), ultimately from IE mereg- "edge, border". However, the well-established meaning of -briga makes this explanation unnecessary.

Conistorgis - Traditionally located in southern Portugal, location of the Conii. For an alternative root *koni(o)-, see Conimbriga. Although the ending -torgis, also seen in Amtorgis (Livy 25, 32, 5), was previously explained as Illyrian -dorgis "city" (TovAR 1957: 278-80), VILLAR (1995a: 211) relates it to *turk-/turg- in Iliturgi and Turgalium. Another possibility is to divide the name as Coni-storgis, from IE *(s)terg- "rigid, firm" (MoRALEJo Álvarez 2003: 191), though this gives a less than satisfactory meaning. The correct etymology remains elusive.

Contobris - This name, recorded by Diodorus Siculus $(33,24)$ and of uncertain location, could come from IE *konto- "point", plus bris (variant of Celtic briga), perhaps referring to a conical hill-fort (PRósPER 2002: 381). However, it might also be a corruption of Centobriga, a town of Celtiberia (TOVAR 1976: 270).

Contosolia - On *konto- "point" see Contobris. The element -soli-, of unclear meaning occurs in Gaulish PNs (Solibis, Solico, Solimarus, Solirigus, Solirix etc.: Whatmough 227-8; from IE *sawel- "sun", MIr sól) as well as the GN Curiosolimagus and EN Coriosolites (RIVET \& SMITH 1979: 320). 
Cottaeobriga - Like Gaulish PNs in Cott- (EvANs 1967: 186-7), this name comes from Celtic *cotto- "old". The same element is seen in the Hispanic PN Corocotta, the Gaulish EN Atecotti, and the Alpes Cottiae. On briga, see Arabriga.

Cynegeticum promontorium - "Kynetes" is the hellenized form of the Conii or Cunei, a people of the Algarve (TOvar 1976: 193).

Deobriga - Clearly Celtic, from *deivo- "god" plus briga "hillfort". Another Deobriga is attested among the Autrigones, and a Deobrigula among the Turmogi.

Deva - Stephanus of Byzantium (p. 229 Meineke) lists a Lusitanian city "Dia" near the ocean. This would be the Greek equivalent of Celtic Deva, both names deriving from IE * deiwo- "divine". There is a town Deva (Chester) in Britain, and a river Deva in Cantabria.

Dipo - While VILLAR (2000: 87) would explain this as -ipo (as in Olisipo) with a prefix $d$-, there is no independent evidence for such a prefix. However, it might be a contraction of $* d i-i p o$, from IE $*^{*} d^{u}$, $d^{u} i$ "two".

Durius flumen - Explained by early scholars as Ligurian or Illyrian, this hydronym and its variants (Duria in the Alps, Duria on the Danube, Duris in Ireland, French rivers Dore and Doron) occur frequently in Celtic lands and appear to represent a Celtic *duro- (LoEWENTHAL 1927-28) from IE *dheu- "to flow". The same IE root may be represented by the river Turia on the east coast.

Eberobriga - From the same root as Ebora and Eburobrittium, due to variable vocalization of the medial syllable.

Ebora - Though HOLDER considered it Iberian (1896-1907, vol. I: 1394), the root is surely Celtic *eburo- "yew tree", from IE *ereb(h)"dark red or brown". Parallels include Ebora in Galicia and Sedetania, Eborodunum in Italy, Eburodunum in Germany, Eburobriga and Eburomagus in Gaul, Eburacum in Britain, and the PNs Eburus (Lusitania) and Eburius (Gaul).

Eburobrittium - Like Ebora, this comes from Celtic *eburo-. -britt- is also Celtic, from IE *ber- (RIVET \& SMITH 1979: 313); compare Brittia, Brittones, etc. (Tovar 1976: 263). 
Elbocoris - *elbho- appears to be a colour term (IE *el- "red", *eluo- "yellow", POKORNY 1959: 302), cf. the Celtic PN Elvorix. The element coris is possibly from IE *keu- "to swell", indicating a hill.

Elet(us) flumen - Known from a dedication to the Aquae Eleteses (HAEp., 1315); from the last word comes the river's modern name, Yeltes. $* E l$ - is an IE colour term (see Elbocoris). The ending -eto- is seen in the GNs Toletum, Oretum, Boletum, etc. In southern Gaul is a river Heledus (Avienus, Ora Maritima, 592).

Emerita Augusta - Latin name, referring to a colony of army veterans (emeriti) founded by Octavian in 25 B.C. The fact that he did not become Augustus until 23 B.C., together with the abbreviation C(olonia) I(ulia) A(ugusta) E(merita) on tiles, pottery and lead pipes, has raised speculation that the colony was originally named Emerita Iulia, though this remains controversial (FARIA 2006: 212-17).

Equabona/Aquabona - The spelling Aqua- appears to be a latinization of an indigenous Equo/a-, seen in PN Equaesus, GN Equosera, EN Equaesi. The root seems to be Celtic *ec ${ }^{u} O$ - "horse", cf. Irish ech, Gaulish epo- (Evans 1967: 197-99). The ending bona, seen in various Gaulish GNs (Augustobona, Colobona, Iuliobona, Vindobona), means "foundation", cognate with German Bau "building", Irish both "hut", from IE *bheue- "to exist, grow".

Etobri(s) - Attested, in the form "Etobrico", as an epithet of the god Bandua. If this is to be understood as *Aetobris it might come from IE *aidh- "to burn", but this would imply hot springs which cannot be verified because of the uncertain provenance (PEDRERO 2001: 544). A philological connection with Etobesa on the Ebro is excluded, as the alternate spelling Otobesa for the latter site is vindicated by the form otobesken on coins.

Euandriana - Neither a Greek etymology (eu-andria "good place for men") nor a foundation by an Evander seems convincing. The Gaulish PN Euenus and Aquitanian GN Euaun... (WhATMOUgh 1970: 212, 363) suggest a possible Celtic derivation.

Fraxinum - Another Fraxinum is located in the south-east, between Tugia and Acci (IA 404,4). Both probably come from Latin fraxinus "ash tree". 
Geraea - Probably from IE * gher- "to enclose", indicating a walled settlement.

Gerticos - same root as Geraea.

Herminius mons - Possibly from IE *erm- "huge" plus *men- "to tower" (whence Latin mons, Welsh mynydd "mountain"). Probably cognate are the Germanic ENs Hermiones and Hermunduri and the Belgic GN Hermoniacum.

(H)instinium - Epigraphically attested by the epithets Histiniensis (HAEp., 212) and Instiniensis (AE, 1971, $146=H E p ., 7,168 \mathrm{a})$. Despite uncertainty over the prefix, the central root may be IE *sten- "narrow", whence Greek ste(i)nos. If the correct spelling is Histinium, it may be related to Ptolemy's GN Istonium (de-aspirated from *Histonium?) in Celtiberia.

Iapiobis/Iapiobica - Possibly contracted from -bris/briga (on which see PRÓSPER 2002: 358-60), but -bis does occur in Celtic GNs, e.g. Toesobis (Britain), Triobis (Aquitanian river), Cantioebis (Upper Germany). VILlaR (2002: 278) would see -obica as comprising *ub$/ o b-$, characteristic of southern Iberian and Pyrenean toponymy, plus -iko. Iapio- finds possible parallels in the Illyrian EN Iapodes (HOLDER 1896-1907, vol. II: 10) and the Gaulish PN Iapis (WhatMough 1970: 214), though the latter might be Greek.

Ierabriga - see Lerabriga.

Igaeditani - Probably named after the DN Igaedus, attested on an altar from Idanha-a-Nova (ILER, 5995). The first element may be paralleled by the Baetican GN Igabrum. -itani is a west Mediterranean suffix (FAUST 1966), though here found well inland.

Interamnienses - Presumably Latin, referring to a town between two streams. Cf. Interamnium Flavium in Asturias.

Ipse - Attested by coins of Ipses as well as in the new Artemidorus papyrus (KRAMER 2005: 28).

Katraleukos - Although this name has been explained as *Castra Leuka (TovAR 1976: 214) or as a Greek translation of Ad Lucentum (AlarCão 2004: 324), the most likely etymology is Celtic *atro- (Old Irish cathir "city", Welsh cader "fortress", from IE *kat- "twist toge- 
ther") plus *leuco- "light". Cf. the PN Catro, attested at Abrantes ( $A E$, 1982, 472).

Laccobriga - Paralleled by Lacobriga of the Vaccaei and Lacca in Baetica. The likeliest root is IE *lakuo- "lake", therefore "lake-town" (PRÓSPER 1997).

Lacinimurgi - Another derivative of *lakuo- "lake", paralleled by Lacimurgi in Baetica, if indeed they are not the same place (see RAMÍREZ SÁDABA 2002: 105-6; SÁEZ FERNÁNDEZ 1994: 100-05). The element murgi comes from IE * $m H_{3}$ rg- "marsh" (SCHMOLL 1959: 84).

Lacipaea - Paralleled by the GN Lacipo in Baetica and the Lusitanian DNs Lacipaea (ILER, 859, Mérida), Lacibaea (HEp., 6, 187, Albalá del Caudilla, Cáceres). The town is presumably named for the deity, whose name may be derived from IE *lakuo- "lake".

Lama - Less likely from Celtic *(p)lama "hand" (so GARCíA Alonso 2001: 394) than from IE *lama "marsh, bog" (PoKORny 1959: 653). It is paralleled by Lambris in Galicia and numerous modern Lama- toponyms in the Iberian Peninsula.

Lancia - Probably from *lonka/lanka "river valley", from IE *lenk"to bend" (GARCíA AlONso 2001: 390). A homonymous town is located in Asturias, and a PN Lancius is attested at Mérida (CIL, II, 573).

Lancienses Transcudani - See Lancia. Trans- is Latin; Cuda is possibly the ancient name of the river Coa (SCHULTEN 1955: 352).

Langobriga - Though some (PRÓSPER 1997; SEVILLA RodRíGUEZ 1980) would derive this from *lonka/lanka "river bed" (see Lancia), a likelier root is Celtic *longo- "long" (CARNOY 1907: 13; GARCÍA Alonso 2001: 390), whence also the PN Lango (GRUPO MÉRIDA 2003: 210). The meaning is thus "elongated hill-fort".

\section{Lanobris - see Londobris}

Lavara - If not an error for Talabara (TovAR 1976: 252), this name may be paralleled by the DN Lavaratus in the Maritime Alps (CIL, XII, 5702) and GN Lavatris in Britain, from IE *lav- "to wash", referring to a local river.

Lennium - Possibly paralleled by the DN Lenus in Belgica and Britain, and the Merovingian mint Lenna (HOLDER 1896-1907, vol. II: 
183). The - $n n$ - combination is presumably assimilated from - $n d$ - (ALARCÃo 2004: 336). The name is Celtic, cognate with Old Irish leni "meadow", Scots Gaelic lèana "boggy meadow, marsh", Breton lenn "pool”, Gaulish GN Lindo-magus, from IE *lendh- "wet, spring".

Lerabriga/Ierabriga - Most easily explained as Lerabriga, either from IE lei- "flow" (Old Irish ler, Welsh llyr "sea") or as cognate with Early Irish lerg "a plain". There is a GN Lera in Ireland (HoGAN 1910: 483).

Leuciana - If not an error for Liciniana, it is paralleled by Katraleukos, Pyrgoi Leukoi (see below, Turres Albae), Contrebia Leucade, Leuca and Leucomagus (Britain), Leuconum (Pannonia) and the EN Leuci (Belgica), from Celtic *leuco- "bright, shining".

Liciniana - Possibly named for a camp of P. Licinius Crassus, praetor in Hispania Ulterior in 97 BC (SCHULTEN 1926: 213). However, there are numerous other Licinii in Lusitania (GRUPO MÉRIDA 2003: 212-13).

Lisangl(um) - Celtic, not from *lisan- "linen" (HoLdER 1896-1907, vol. II: 239) but from *pliss- "enclosure" (Early Irish liss, Old Breton lis) from IE * plet- "broad" (MACBAIN 1911: 230). The element angl- comes from IE *ank-/ang- "to bend" with - ul extension, as in Greek ankylos "crooked, bent", French and English angle. The name should therefore mean "crooked enclosure".

Lomondo/Lomundo - From IE *lomos "broken, part" (MANN 1984-87: 708). Possibly paralleled by the Lomacensis pagus in medieval Belgica (HoLDER 1896-1907, vol. II: 281).

Londobris/Lanobris insula - Though Lanobris is the easier name to explain (from Celtic *lano- "flat, plain"; cf. the dedication to Bandue Lanobrigae at Eiras, Orense - HEp., 1, 492 - which some scholars would however read Lansbricae or Alanobrigae), this form is attested only in the Periplus of Marcianus, which is dependent on Ptolemy. Since Ptolemy gives Londobris, Marcianus is apparently mistaken. The obvious parallel is Londinium in Britain. Though GARcía Alonso (2006) interprets Londobris as "Londo's fortress", the toponym comes less likely from a PN than from IE * $l_{3} n d h$ - "land" (PRÓSPER 2002: 381). On -bris see Contobris. 
Lubancum - GN assumed from a dedication to Lares Lubanc(i) Douilonicorum (Tovar 1976: 262). It seems paralleled by the Lubaeni, a people of Galicia (Ptol., 2, 6, 47) and the PN Lubana (ILER, 4309, Idanha a Velha). It may be related to Old Irish lúb "bend, loop", perhaps referring to those who live at a river bend.

Lusitania - Fancifully derived by Varro from lusus or lyssa (Pliny, NH, 3, 8) and by GouveIA (1970) from Anatolian luth "light-stone" $+y$ thania "land of the river of heaven", the name is more sensibly connected with the Celtiberian EN Lusones and the Celtic PNs Luso, Lusia. The ultimate root is undetermined.

Malateca - The root *mal-/mel- which occurs frequently in European GNs, comes from IE *mel- "to stand out, be elevated" (VILLAR \& PRÓSPER 2005: 70). There are several places named Mala in Ireland (HoGAN 1910: 536), where mala means "brow, hillside". The ending teca should mean "dwelling", cf. Old Irish tec "house" from IE *tego"roof, covering". Malateca therefore denotes an elevated settlement.

Manliana - Clearly named for a Manlius. However, this is not a villa named for a possessor Manlius (AlARCOS 1950: 475; GARCíA Alonso 2003: 213), since Ptolemy lists it as a city. The eponym may therefore be the praetor P. Manlius (Vulso?), who campaigned in Ulterior in $182 \mathrm{BC}$.

Matusarum - Celtic *mati-, variant *matu- "good" (EvANs 1967: 229 ) is seen in the common PN Matugenus as well as in Celtiberian inscriptions (matus, matulokum). Paralleled by Irish maith, Welsh mad "good" and Latin maturus, it comes from IE *ma- "good, opportune" (POKORNy 1959: 693). Sar- is possibly a hydronym, cf. the river Sararus (modern Saar) in Belgica and the possible river Sarnikio at Botorrita. Alternatively it could come from *sagro- "strong", from IE *seg-, with the "g" lost through lenition: "the good, strong place".

Me(i)dubriga - Paralleled by Meidunium castellum in Galicia (CIL, II, 2520) and the PNs Meducenus/Meiduenus (GRUPO MÉRIDA 2003: 237). A derivation from medhu "mead" (AlberTos 1966: 153) seems unlikely for a GN. One possibility is Celtic *meido- "fame, glory", whence Old Irish míad "honour", glossed fastus "pride" (SтоKES 1894: 205; CARNOY 1907: 20), therefore "glory town". On the alternation of $o / u$, see Monda/Munda. An alternative is *medu- "woods, 
border", proceeding from IE *medyo-, medhu- "middle" since woods often formed the boundary between territories. This root is reflected in words for "wood" in some Balkan languages, though its existence in western Europe remains hypothetical. ANREITER, HASLINGER \& ROIDER (2000: 124-25) see it as the base for the river-name Medoacus/Meduacus (note again the $o / u$ alternation) in northern Italy, as well as for the GNs Medullum (western Tyrol) and Mons Medullius (Asturias). However, the etymology of Meidubriga remains in question.

Mendiculeia - Paralleled by a homonymous GN among the Ilergetes. TOVAR (1976: 272) thought both were Italian foundations, citing a Mendicoleius vicus in Lucania. But all these could come from IE *mento- "projection", cf. Cornish menedh "hill", Welsh mynyddig "hilly". A less likely possibility is Celtic *mendo- "kid, young ram" (HoLDER 1896-1907, vol. II: 547) from IE *mend- "small animal".

Metellinum - Evidently named for Q. Caecilius Metellus Pius, governor in $79 \mathrm{BC}$.

Mirietanorum civitas - Probably from the same root as Mirobriga, q.v.

Mirobriga - Located west of Salamanca, according to the boundary stones, and paralleled by another Mirobriga in western Baetica near Capilla. Miro- is amply attested as a hydronym, possibly from IE *meir- "to wander" (PEDRERo 1996: 362), and may be seen in modern GNs Miranda (*miro-randa: CoRominas 1972: 91-95). However, the Lusitanian DN Mirobieus (ILER, 881) and the PN Miro (CIL, II, 3384, and a Miro Conimbrensis episcopus in AD 683) suggest that there is also a non-hydronymic root, perhaps cognate with Latin mirus "wonderful".

Monda/Munda flumen - This name for the river Mondego (the modern name comes from the adjectival form *Mondaecus) is paralleled by a GN Munda in Baetica and the PNs Monda (Aquitania, WHATMOUGH 1970: 416) and Mundicius (Lusitania). The interchange of $o / u$ is frequent in Hispanic toponymy (VILLAR 2000: 369-76). The root is IE * $m H_{3}$ ndo- "bright, clear".

Montobrica - Possibly a Roman hybrid, from Latin mons, montis plus Celtic -briga. 
Moron - Seemingly paralleled by the GN Morodon (Galicia), Moroica (Cantabria) and the EN Morogi (Varduli). However, while these may come from *mor- "sea", Moron is located inland. The root may therefore be IE *moro- "large, great", Irish mór, Breton moer (MANN 1984-87: 798).

Myrtilis - The ending -ili(s) is seen in several other GNs, e.g. Bardili, Bilbilis, Ocilis, Sacili (VILlar 2000: 266). Myrt- is unlikely to come from Latin myrtus "myrtle" and should be of indigenous origin, though parallels are lacking.

Norba - Named for C. Norbanus Flaccus, consul in 38 BC (TovaR 1976: 236). There are dozens of Norbani in Lusitanian epigraphy (GRUPO MÉRIDA 2003: 248-50).

Obila - see Abila.

Ocelum - Paralleled by Ocellum (Galicia), Ocelodurum (Vaccaei), Ocilis (Celtiberia), Ocelo (Alps). The root is Celtic *ocelo- "promontory" (CURCHIN 1996: 46).

Olisipo/Olysipo - The ending -ipo has many attestations in southern Iberia, and the prefix $O$ - is possibly paralleled by Obulco in Baetica. The element lis-/lys- may be the same as in Lusitania.

Ossonoba - The ending -oba/-uba, labelled IE by VILLAR (2000) but non-IE by UnTERMANN (2001: 201), is paralleled in Baetica by Onoba, Maenuba etc. Oss- may come from IE *os "river mouth" (Latin ostium).

Otobesa - Paralleled by homonyms in Edetania and on the Ebro (see Etobris). Probably from IE *okto- "eight".

Oxthracae - The largest town of the Lusitani, according to Appian (Iberica, 58). The ending - aca is paralleled by Autraca, Arriaca, Pisoraca etc. Possibly from IE *oks- "sharp" and *dragh- "rough, rugged", therefore "sharp rugged place"? An alternative possibility is suggested by Old Irish uachtar, ochtar "surface, summit" from Celtic *oucterofrom IE *eug-/ueg- "rise, be vigorous".

Paesures oppidani - Pliny $(\mathrm{NH}, 4,113)$ lists the Paesuri as a people of Lusitania, cf. the Paesici in Galicia and the Lusitanian DN Paisicaicus (ENCARNAÇÃO 1975: 256). The meaning of paes- remains obscure. 
Palantenses - Paralleled by Palantia of the Vaccaei. The -nt-infix is IE. Pal- may come from *pal- "marsh" or *pala- "plain" (BÚA 1999: 324).

Patulus Portus - Latin, meaning "open harbour".

Pax Iulia - Latin, meaning "Julian peace". island.

Pelagia insula - From Latin pelagus "sea", referring to an oceanic

Plagiaria - "Robbers' roost", from Latin plagiarius "thief". The Lusitanians were notorious for banditry.

Poetanium insula - While Schmoll (1959: 15) considers this name Punic, Holder (1896-1907, vol. II: 1026) lists the Pannonian GN Poetovio as Celtic. There is also a Roman PN Poetelius. It is unclear whether all these Poet- names come from a common root.

...polibeda - Possibly [I]polibeda, though located further north than any other Ipo- name. The suffix -beda is seen in the Iberian oronyms Idubeda and Orospeda.

Portus Hannibalis - Since the Carthaginian general Hannibal did not campaign in Lusitania, this GN may refer to a Phoenician settler of the same name. Cf. (insula) parva Hannibalis (Pliny, $N H 3,5,76$ ) in the Balearic islands, which were also not visited by the famous Hannibal.

Reuvean - Though listed by TOVAR 1976: 233, this is a misunderstanding of a dedication to the god Reve Anabaraecus (CIL, II, 685).

Rodacis - Probably from the same root as Rouda/Rauda, see below. Cf. the EN Ambirodacus, applied to a native of Uxama (CIL, II, 4306).

Rouda - Attested by an inscription naming the vicani Roud(enses) (CURCHIN 1985: 330)

Given the confusion between "a" and "o" sounds (see Abilal /Obila), this name may come from the same root as Rauda of the Vaccaei, namely IE *reudh-/roudh- "red" (cf. Old Cornish rud, Welsh rhudd), presumably referring to the colour of the soil (CuRCHIN 1997: 271-72). The DN Bandue Roudaecus, with adjectival ending -aikos ( $A E$, 1977, 430 and 432, cf. PEDRERO 2001: 551) is clearly related. 
Rusticiana - Latin, derived from the PN Rusticus, Rusticius, or Rusticianus. There are numerous attestations of the name Rusticus in Lusitania (GRUPO MÉRIDA 2003: 288).

Sacrum promontorium(Hieron akroterion) - The Latin and Greek names for Cape St. Vincent.

Salacia - Its location near the mouth of the river Sado warrants its derivation from IE *sal- "salt".

Sallaecus - Located inland by Ptolemy, its root should be IE *sal"water current" with adjectival ending -aecus.

Salmantica - Composed of IE *sal- (see Sallaecus) plus the IE suffix -mant-.

Scallabis - The root is probably IE *skal- "point", Cornish ascal "thistle", Norse skali "headland". The element - $a b$ - is well known as an IE hydronym (ALARCÃo 2002: 38).

Seanoc $(i)$ - Apparently from Celtic *seano- (possibly from IE *se- "to bind") which refers to an undefined type of plant (CARNOY 1907: 36) that presumably grew on this site. A lost inscription from Numantia (CIL, II, 2838) records the name NONIVS QUINTILIANVS SFANIOCVM, which AlberTos (1979: 159) interpreted as "S(exti) f(ilius) Aniocum". However, the deditio of Seanoci (LóPEz MELERO ET AL. 1984) makes the reading "S[e]aniocum" more likely.

Sellium/Seilium - Despite the existence of PNs Sellius/Seilius, the likeliest root is IE *sed- "sit", *sedl- "settlement" (POKORNY 1959: 886). There is a GN Selia in Baetica, and an oronym Sellus on the Mediterranean coast of Hispania (Avienus, Ora maritima, 507).

Sentica - Located south of Salmantica, it has a homonym among the Vaccaei. The root is Celtic *sento- "path" with suffix -ica (CURCHIN 1997: 274).

Serpa - Either from IE $1 *$ ser- "to flow" or $2 *$ ser "to protect (POKORNY 1959: 909-910). The ending -pa is claimed as a variant of -ipo by VILLAR (2000: 98), though this is debatable.

Statio Sacra - Latin.

Tabucci/Tacubis - Ptolemy's Tacubis, if correct, might be related to the river Tagus and the Bastetanian city Tagili. However, the form 
Tabucci (Antonine Itinerary) offers more fruitful possibilities, such as the GNs Tabaniu (Iberian mint) and Taburnus (Narbonensis), the Lusitanian DN Tabudicus (HAEp., $1928=I L E R, 930)$, and the PNs Tabius, Tabaesius and Tabola (WhatMough 1970: 228; GRUPO MÉRIDA 2003: 312). The ending - ucci is well attested in Baetica (Tucci, Arucci, etc.)

Tagus flumen - Not credibly from Phoenician dag "fish" or Celtic *dago- "good". MacAodHA (1981: 75) derives it from Latin tagus "ravine" - but there is no such Latin word. Hispanic PNs in Tac-/Tagare probably unrelated, being variants of Tanc-/Tang-, ultimately from IE *tenk- (PALOMAR LAPESA 1957: 100-02), though a few may be Celtic, e.g. Taganus (GruPo MÉrIDA 2003: 311), cf. Gaulish Daganius (Evans 1967: 188). But the likeliest etymology for Tagus is IE *(s)tag"to drip", whence Latin stagnum "pool".

Talabara - Although tala- has been explained as an Old European hydronym from IE *(s)tel- "pour, pool" (VILLAR 1993: 289), a likelier root is IE *tel(o)- "flat", whence Old Irish talam "earth", Welsh tal "brow", Sanskrit talas "level ground", Latin tellus "earth" (POKORNY 1959: 1061). The element -bar-possibly recurs in the divine epithet Anabaraecus (CIL, II, 685).

Talabriga/Talabrica - Though both spellings are attested, the second element is clearly -briga (see Arabriga). On tala-, see Talabara. The significance is evidently "flat hilltop".

Tamusia - Spelled taimuçiensis on an Iberian tessera from Villasviejas de Tamuja (HEp., 6, 221). It belongs to a large series of Old European names formed from the hydronym *tam-, from IE *tem- "cut", including the river Tamesis in Britain, and the Fontes Tamarici in Cantabria (VILLAR 1995b).

Tapori/Talori - Despite the (erroneous?) form Talori in CIL, II, 760, Tapori is vindicated by Pliny and numerous epitaphs (ALARCÃO 1988: 19). It is probably the genitive of the PN Taporus, attested eleven times in Lusitania (GRUPO MÉRIDA 2003: 316). The root Tap-, of uncertain meaning, occurs also in PNs from Noricum, Dacia and Gaul (AlBertos 1966: 221). Cf. the GNs Tapae (Dacia) and Taparum (Africa Byzacena).

Turgalium - Despite a large number of Tor-/Tur- toponyms in the Iberian Peninsula, their origin remains a problem (see Conistorgis). 
VILLAR (1993) takes tur- as the outcome of the zero grade of IE *ter"wipe, pierce", but this remains conjectural. A Celtiberian coin (UNTERMANN 1975: $\mathrm{n} .^{\circ}$ A.87) reading roturkom, with ro- for $*(p)$ ro-, brings us no nearer to a meaning. Celtic *turco- "boar" is a possible root, but galcould equally be related to Burdigala in Aquitania. RuBÉn JiménEZ (2005: 520) ingeniously translates "torre o altura de los galos (celtos)", but there is no evidence either for tur as "tower" (notwithstanding Latin turris) or for galium as genitive.

Turibri(ga) - Paralleled by Turobriga in Baetica. On tur-, see Turgalium.

Turmulum/Turmogum - Though connected by SchUlTEN (1948: 1393) with the Turmogi of north-central Spain, Ptolemy's Turmogon is more likely a manuscript error for Turmolon, due to the easy confusion of majuscule gamma and labda. Turmo- names are very common (cf. VILLAR 1995a, index).

Turol( $i$ ) - Probably related to the PN Turol(i)us, attested in Lusitania (GRUPo Mérida 2003: 328) and the DN Turolici (VILlar 1995a: 147). On tur-, see Turgalium.

Turres Albae - Latin name presumed from Ptolemy's Pyrgoi Leukoi. "Turres" may refer to a hillfort, cf. Turris Lascutana, Turris Regina, Ad Turres, etc.

Vacua flumen - From the Celtic hydronym *uek-/uak- "curved" (cf. Latin vacillare, Welsh gwaeth "worse"). Paralleled by the river Vacalus (Lower Germany), the GN Vacontium (Pannonia) and the ENs Arevaci, Vaccaei, Bellovaci (Gaul), Vacomagi (Britain).

Velladis - Listed only in secondary manuscripts of Ptolemy. If a real place, it may be related to the Gaulish and British DN Vellaunus, GNs Vellica (Cantabria), Vellaunodunum (Gaul) and Vellanis (Moesia Superior), and ENs Vellavi (Gaul), Vellates (Aquitania), Catuvellauni (Britain), Segovellauni (Narbonensis) and Vellabori (Ireland). The root may be IE *uel- "to turn" (BASCUAS 1999) whence possibly Latin vallis "valley".

Venia - Known from an inscription naming the Venienses vicani (AE, 1979, 330). The root is Celtic *ueni- "kin, family" (Old Irish fine), seen in the ENs Veneti (Lugdunensis), Venami (Aquitania) and Venic- 
nii (Ireland). Another town Venia is implied by the word veniakum on a Celtiberian tessera from Viana, Navarra (LABEAGA \& UNTERMANN 1993-94: 49). There is also a road station Veniatia in Asturias.

Verurium - This name probably contains the IE hydronym *ur“water". The proposal of SCHMOLL (1959: 92) to construe Verurium as Celtic *uper-urium was accepted by Tovar (1976: 259) and VILLAR (2000: 199). But it may be better to understand the name as Veru-urium, from Celtic *ueru- "wide, ample", from IE *uer- "broad". This would give a meaning "wide water". Cf. British Verulamium ("wide marsh"?)

Vipasca - The Celtic stem *uipo-, variant of IE *uepo- "water" (PoKORNY 1959: 1149; Holder 1896-1907, vol. III:357), is attested in northern Italy and the Danube. The suffix -asco, traditionally labelled Ligurian, is at any rate Old European.

Visa - Paralleled by the GNs Visentium (Etruria) and Visense oppidum (Numidia), and the GN Visaeclensis (CIL, II, 2981, Egea de los Caballeros, Huesca) and gentilic Visancorum (Ficheiro Epigráfico, 72, Penela da Beira). The likely root is IE *uis- "wet, pasture", cf. Welsh gwaen, Old High German wisa "meadow".

\section{Conclusions}

The foregoing discussion of individual names is a necessary prelude to conclusions about the linguistic origins of Lusitanian toponyms. From this discussion, the names may be classified as follows. Toponyms whose attribution to a language category is considered probable but not absolutely certain, are followed by "(?)". In cases where probability was not apparent, I have listed the names as "Uncertain", rather than making a subjective judgment that might skew the results. Names ending in -briga are not counted as Celtic unless the preceding element is also Celtic. Caurium.

Pre-Indo-European (3 names $=2 \%$ of total $)^{3}$ : Araocelum, Aravi,

Indo-European, undifferentiated $(56=33.5 \%)$ : Abila, Adrum, Alantune, Ammaia, Ana, Arbua, Areva, Baedorus, Baesuri(?), Barba-

\footnotetext{
3 The total number of toponyms is 167 .
} 
rium, Braetolaeum, Caeilobrigoi, Caelionicoi, Caliabriga, Calontenses, Caluri, Coerenses, Colarni, Elbocoris, Eletus, Geraea, Gerticos, Herminius, Hinstinium, Laccobriga, Lacinimurgi, Lacipaea, Lama, Lancia, Lancienses Transcudani, Lavara, Lerabriga, Lomondo, Malateca, Mendiculeia, Miretanorum civitas, Mirobriga, Monda, Moron, Ossonoba(?), Otobesa, Oxthracae, Palantenses, Rodacis, Rouda, Salacia, Sallaecus, Salmantica, Scallabis, Sellium, Serpa, Tagus, Talabara, Talabriga, Tamusia, Visa.

Celtic $(50=30 \%)$ : Abelterion, Aeminium(?), Agonis(?), Arabriga, Arandis, Arcobriga, Arcuce, Aritium, Balatucelum, Baniensis civitas(?), Bletisama, Burdua, Burrulobriga, Caetobriga, Cairieses, Camalocenses, Capara, Celticoflavium, Cenum, Cinginnia, Cobelcorum civitas(?), Collippo, Conimbriga, Contobris(?), Contosolia, Cottaeobriga, Deobriga, Deva, Durius, Eberobriga, Ebora, Eburobrittium, Equabona, Euandriana(?), Katraleukos, Langobriga, Lennium, Leuciana, Lisanglum, Londobris, Lubancum(?), Matusarum, Ocelum, Seanoci, Sentica, Vacua, Velladis, Venia, Verurium, Vipasca.

Iberian $(2=1 \%)$ : ...polibeda, Tabucci(?).

Latin $(30=18 \%)$ : Ad Lippos, Ad Septem Aras, Ad Sorores, Augustobriga, Caeciliana, Caepiana, Caesarobriga, Castra Caecilia, Castra Servilia, Castrum Colubri, Cauliniana, Centum Cellae, Concordia, Emerita Augusta, Fraxinum, Interamnienses, Liciniana, Manliana, Metellinum, Montobrica(?), Norba, Patulus Portus, Pax Iulia, Pelagia, Plagiaria, Portus Hannibalis, Rusticiana, Sacrum Promontorium, Statio Sacra, Turres Albae.

Uncertain $(26=15.5 \%)$ : Achale, Aebosocula, Araducta, Balsa, Callipous, Capsiana, Chretina, Cilibe, Conistorgis, Cynegeticum, Dipo, Etobris, Iapiobis, Igaeditani, Ipse, Lusitania, Meidubriga, Myrtilis, Olisipo, Paesures, Poetanium, Tapori, Turgalium, Turibriga, Turmulum, Turoli.

Although the origins of some $15 \%$ of Lusitanian toponyms cannot be plausibly identified, several conclusions of a linguistic nature may be drawn. First, it is noteworthy that $30 \%$ of the names appear to be Celtic, while a similar quantity $(33.5 \%)$ appear to be non-Celtic Indo-European. These close figures provide equal weight of support to arguments on both sides of the continuing debate as to whether Lusitanian is, or is not, a Celtic language (cf. GoRROCHATEGUi 1994: 14-15, with further 
bibliography). If Lusitanian is not Celtic, scholars must somehow account for $30 \%$ of the toponyms being loanwords from Celtic; if Lusitanian is Celtic, they must account for a large, underlying and presumably anterior Indo-European stratum. It may be helpful to compare the case of the Arevaci, one of the subgroups of the Celtiberians, among whom one would expect a high proportion of the names to be Celtic. However, only $36 \%$ of its toponyms are Celtic, while another $36 \%$ appear to be non-Celtic Indo-European (CURCHIN 1997: 277). It may perhaps be wisest to classify Lusitanian as "para-Celtic", a language of peoples bordering on, and strongly influenced, by Celtic speakers, but having strong roots in Old European.

For those interested in the impact of Romanization, it may be noted that nearly one-fifth of the toponyms are Latin. However, many of these refer to mansiones on the Roman highways, and are thus road stations rather than towns. Others are Roman colonies or municipalities whose names include the imperial elements "Caesar", "Iulia", or "August-".

In sum, these toponyms provide valuable source material for studying the interaction and overlap of several different languages in the region of ancient Lusitania. While the present article cannot claim to have definitively identified the language of every name, it is hoped that this survey of the status quaestionis will provide a starting point for further investigation.

\section{BIBLIOGRAPHY}

AlarCão, J. DE (1988) - Roman Portugal, Westminster.

AlarCÃo, J. DE (2002) - "Scallabis e o seu território", De Scallabis a Santarém, Lisboa, pp. 37-59.

AlARCÃo, J. DE (2004) - "Notas de arqueologia, epigrafia e toponímia - I", Revista Portuguesa de Arqueologia, 7.1, pp. 317-342.

Alarcos, E. (1950) - "Apuntaciones sobre toponimia riojana", Berceo, 5 (n. $\left.{ }^{\circ} 16\right)$, pp. 476-492.

Albaigès, J. M. (1998) - Enciclopedia de los topónimos españoles, Barcelona.

Albertos, M. L. (1966) - La onomástica personal primitiva de Hispania Tarraconense y Bética, Salamanca.

Albertos, M. L. (1979) - "La onomástica de la Celtiberia", Actas del II Coloquio sobre lenguas y culturas prerromanas de la Península Ibérica, Salamanca, pp. 131$-167$. 
Albuquerque, J. P. M. (1962) - "Tribos celtas e pré-celtas do norte da Lusitânia gravadas na toponimia", 26. ${ }^{\circ}$ Congresso luso-espanhol para o progresso das ciências, Porto, pp. 201-211.

Anreiter, P., Haslinger, M. \& RoIder, U. (2000) - "The names of the eastern Alpine region mentioned in Ptoloemy", Ptolemy. Towards a linguistic atlas of the earliest Celtic place-names of Europe, ed. D.N. Parsons \& P. Sims-Williams, Aberystwyth, pp. 113-42.

Bandeira Ferreira, F. (1959) - "A propósito do nome Achale o Acala da Ora Maritima de Avieno", Revista de Guimarães, 69, pp. 437-444.

BASCUAS, E. (1999) - "Ulla, Veleia y otros derivados de la raíz indoeuropea wel- 'hacer girar'", Veleia, 16, pp. 159-216.

BASCUAS, E. (2002) - Estudios de hidronimia paleoeuropea gallega, Santiago de Compostela.

Bertoldi, V. (1953) - "Contatti e conflitti di lingue nell'antico Mediterraneo", La Parola del Passato, 8, pp. 407-448.

Blondin, R. (1977) - "Le toponyme Conimbriga”, Conimbriga, 16, pp. 145-159.

BÚA, C. (1999) - "Hipótesis para algunas inscripciones rupestres del Occidente peninsular", Pueblos, lenguas y escrituras en la Hispania prerromana, ed. F. Villar \& F. Beltrán, Salamanca, pp. 309-327.

CARnoy, A. J. (1907) - "Éléments celtiques dans les noms de personnes des inscriptions d'Espagne", Le Muséon, 26 (nouvelle série, 8), pp. 1-40.

Cerrillo, E. (1993) - "Leyenda y arqueología de las ciudades prerromanas. Caparra", Leyenda y arqueología de las ciudades prerromanas de la Península Ibérica, vol. II, Madrid, pp. 149-158.

Corominas, J. (1972) - Tópica hespérica, vol. I, Madrid.

Curchin, L. A. (1985) - "Vici and pagi in Roman Spain”, Revue des Études Anciennes, 87, pp. 327-343.

Curchin, L. A. (1996) - "Five Celtic town-names in Central Spain", Habis, 27, pp. 45-47.

Curchin, L. A. (1997) - "Celticization and romanization of toponymy in central Spain”, Emerita, 65, pp. 257-279.

Curchin, L. A. (forthcoming) - "Toponymy of Lusitania. Myth and reality", VI Mesa-redonda sobre a Lusitânia Romana, Coimbra.

Dauzat, A. \& Rostaing, C. (1963) - Dictionnaire étymologique des noms de lieux en France, Paris.

ENCARNAÇÃo, J. D’ (1975) - Divindades indígenas sob o domínio romano em Portugal, Lisboa.

Evans, D. E. (1967) - Gaulish personal names, Oxford.

FARIA, A. M. DE (2006) - "Novas notas historiográficas sobre Augusta Emerita e outras cidades hispano-romanas", Revista Portuguesa de Arqueologia, 9.2, pp. 211-237.

FAUST, M. (1966) - Die antiken Einwohnernamen und Völkernamen auf -itani, -etani, Göttingen.

GARCíA AlOnSO, J. L. (2001) - "Lenguas prerromanas en territorio de los vetones a partir de la toponimia", Religión, lengua y cultura prerromanas en Hispania, ed. F. Villar \& M. P. Fernández Álvarez, Salamanca, pp. 389-406. 
García Alonso, J. L. (2003) - La Península Ibérica en la Geografía de Claudio Ptolomeo, Vitoria.

García Alonso, J. L. (2006) - "-briga toponyms in the Iberian Peninsula", e-keltoi, 6 (http://www.uwm.edu/Dept/celtic/ekeltoi/volumes/vol6)

GaRvens, F. (1964) Die vorrömische Toponymie Nordspaniens, Münster.

Gorrochategu, J. (1994) - "La lengua de las poblaciones prerromanas del área indoeuropea", Las estructuras sociales indígenas del norte de la Península Ibérica, ed. M. C. González \& J. Santos, Vitoria/Gasteiz, pp. 13-21.

Gouveia, B. (1970) - "A Lusitânia", Revista de Portugal, série A: Língua Portuguesa, 35, pp. 369-376.

GRUPO MÉRIDA (2003) - Atlas antroponímico de la Lusitania romana, Mérida \& Burdeos. Guerra, A. (1996) - "Os nomes do rio Lima", La Hispania prerromana. Actas del VI Coloquio sobre lenguas y culturas prerromanas de la Península Ibérica, ed. F. Villar \& J. d'Encarnação, Salamanca \& Coimbra, pp. 147-161.

Guerra, A. (1998) - Nomes pré-romanos de povos e lugares do Ocidente peninsular, doctoral dissertation, Lisboa.

GuERRA, A. (2004) - "Caepiana. Uma reavaliação crítica do problema de sua localização e enquadramento histórico", Revista Portugesa de Arqueologia, 7.2, pp. 217-235.

Hogan, E. (1910) - Onomasticon Goedelicum locorum et tribuum Hiberniae et Scotiae, Dublin \& London.

HOLDER, A. (1896-1907) - Alt-celtischer Sprachschatz, 3 vols, Leipzig.

Hoz, J. DE (1963) - "Hidronimia antigua europea en la Península Ibérica", Emerita, 31, pp. 227-242.

HÜBNER, E. (1893) - Monumenta Linguae Ibericae, Berlin.

Humboldt, W. von (1821) - Prüfung der Untersuchungen über die Urbewohner Hispaniens vermitels der vaskischen Sprache, Berlin.

HumBolDt, W. vON (1879) - Los primitivos habitantes de España. Investigaciones con el auxilio de la lengua vasca, Madrid.

Johnston, J. B. (1934) - Place-Names of Scotland, 3. ${ }^{\text {a ed., London. }}$

KRAHE, H. (1962) - Die Struktur der alteuropäischen Hydronimie, Wiesbaden.

Kramer, B. (2005) - "El nuevo papiro de Artemidoro", New approaches to Celtic place-names in Ptolemy's Geography, ed. J. de Hoz, R. Luján \& P. Sims-Williams, Madrid, pp. 19-31.

Labeaga, J. C. \& UntermanN, J. (1993-94) - "Las téseras del poblado prerromano de La Custodia, Viana (Navarra)", Trabajos de Arqueología Navarra, 11, pp. 45-53.

LAMBERT, P. Y. (1995) - La langue gauloise, Paris.

Loewenthal, J. (1927-28) - "Duero", Zeitschrift für Ortsnamenforschung, 3, p. 52.

LomAs, F. J. (1980) - "Las fuentes históricas más antiguas para el conocimiento de los celtas peninsulares", in J. M. Blázquez et al., Historia de España antigua, vol. I: Protohistoria, Madrid, pp. 53-81.

López Melero, R., Sánchez Abal, J. L. \& García Jiménez, S. (1984) - "El bronce de Alcántara: Una deditio del 104 a. C.", Gerión, 2, pp. 265-323.

MacAodHA, B. S. (1981) - "Some major elements in Portuguese placnames", Iberian Studies, 10, pp. 75-79. 
MacBain, A. (1911) - An etymological dictionary of the Gaelic language, 2. ${ }^{\mathrm{a}}$ ed., Stirling.

ManN, S. E. (1984-87) - An Indo-European comparative dictionary, Hamburg.

MARques, C. S. (1984) - "Contribuição para o estudo da toponímia do concelho de Vila Nova de Gaia”, Gaia, 2, pp. 101-108.

MeILlet, A. (1969) - Introduction a l'étude comparative des langes indo-européennes, Alabama.

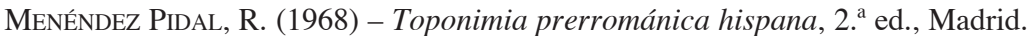

Moralejo Álvarez, J. (2001) - "Hidronimia galaica prerromana”, Religión, lengua y cultura prerromanas en Hispania, ed. F. Villar \& M. P. Fernández Álvarez, Salamanca, pp. 501-509.

Moralejo Álvarez, J. (2003) - "Conimbriga y otros topónimos en -briga”, Lógos Hellenikós. Homenaje al Profesor Gaspar Morocho Gayo, León, pp. 185-195.

Moralejo Álvarez, J. (2005) - “Arco(s), Busto(s), Pazo(s) ¿Toponimia de ganadería?", As tebras alumeadas. Estudos filolóxicos ofrecidos en homenaxe a Ramón Lorenzo, Santiago de Compostela, pp. 219-237.

Palomar Lapesa, M. (1957) - La onomástica personal pre-latina de la antigua Lusitania, Salamanca.

Pedrero, R. (1996) - "El hidrónimo prerromano Mira", Emerita, 64, pp. 361-374.

PEDRERo, R. (2001) - "Los epítetos del teónimo occidental Bandue/i”, Religión, lengua y cultura prerromanas de Hispania, ed. F. Villar \& M. P. Fernández Álvarez, Salamanca, pp. 541-560.

POKORNY, J. (1959) - Indogermanisches etymologisches Wörterbuch, vol. I, Bern.

PrósPer, B. M. (1997) - "Tongoe Nabiagoi. La lengua lusitana en la inscripción bracarense del ídolo de la fuente”, Veleia, 14, pp. 163-176.

PRÓSPER, B. M. (2002) - Lenguas y religiones prerromanas del occidente de la Península Ibérica, Salamanca.

Prósper, B. M. (2004) - "Varia palaeographica occidentalia", Palaeohispanica, 4, pp. 169-194.

Ramírez SÁdAbA, J. L. (2002) - "La onomástica en la Antigüedad. Antroponimia y toponimia”, Els substrats de la llengua catalana. Una visió actual, Barcelona, pp. 103-129.

Rivet, A. L. F. \& Smith, C. (1979) - The place-names of Roman Britain, London.

Rostaing, C. (1958) - Les noms de lieux, Paris.

RubÉn JimÉnEZ, J. (2004) - Diccionario toponímico y etnográfico de Hispania antigua, Pozuelo de Alarcón (Madrid).

SÁEZ FERNÁNDEZ, P. (1994) - "Nuevas perspectivas en relación a la ordenación territorial del sur de la Lusitania española”, Les campagnes de Lusitanie romaine. Occupation du sol et habitats, ed. J. G. Gorges \& M. Salinas de Frías, Madrid \& Salamanca, pp. 99-108.

Schmoll, U. (1959) - Die Sprachen der vorkeltischen Indogermanen Hispaniens und das Keltiberische, Wiesbaden.

Schulten, A. (1926) - "Liciniana", Pauly-Wissowas Real-Encyclopädie der classischen Altertumswissenschaft, vol. XIII, Stuttgart, col. 213. 
Schulten, A. (1930) - "Die Etrusken in Spanien”, Klio, 23, pp. 365-432.

Schulten, A. (1931) - "Mendiculeia”, Pauly-Wissowas Real-Encyclopädie der classischen Altertumswissenschaft, vol. XV, Stuttgart, col. 784.

Schulten, A. (1937) - Fontes Hispaniae antiquae, vol. IV, Madrid.

Schulten, A. (1948) - “Turmulum”, Pauly-Wissowas Real-Encyclopädie der classischen Altertumswissenschaft, vol. VIIA.2, Stuttgart, col. 1393.

SCHulten, A. (1955) - Iberische Landeskunde, vol. I, Strasbourg.

SEVILla RodríGuez, M. (1980) - Toponimia de origen indoeuropeo prelatino en Asturias, Oviedo.

STOKES, W. (1894) - Urkeltischer Sprachschatz, Göttingen.

Tovar, A. (1957) - "Ilirios en Hispania”, Beiträge zur Namenforchung, 8, pp. 278-280.

Tovar, A. (1958) - "Topónimos con -nt- en Hispania y el nombre de Salamanca", Actes et mémoires du cinquième congrès international de toponymie et d'anthroponimie, vol. 2, Salamanca, pp. 95-116.

Tovar, A. (1970) - "Hidronimia europea antigua. Jarama, Balsa", Habis, 1, pp. 5-9.

Tovar, A. (1976) - Iberische Landeskunde, vol. II, part 2: Lusitania, Baden-Baden.

Untermann, J. (1975) - Monumenta linguarum hispanicarum, vol. I. Die Münzlegenden, Wiesbaden.

UnTERMANN, J. (2001) - "La toponimia antigua como fuente de las lenguas hispano-celtas", Palaeohispanica, 1, pp. 187-218.

VAsConcellos, J. LeITE de (1938) - Opúsculos, vol. V: Etnologia, Lisboa.

VILlar, F. (1993) - “Talabara, Talavera, Toledo", Studia palaeohispanica et indogermanica in honorem J. Untermann ab amicis Hispanicis oblata, ed. I. J. Adiego, J. Siles \& J. Velaza, Barcelona, pp. 287-296.

VILlar, F. (1995a) - Estudios de celtibérico y de toponimia prerromana, Salamanca.

VILlAR, F. (1995b) - "El hidronimo prerromano Tamusia, moderno Tamuja", Hispano-gallo-brittonica. Essays in honour of Professor D. Ellis Evans, Cardiff, pp. 260$-277$.

VILlar, F. (1999) - "Los topónimos meridionales de la series ipo", Pueblos, lenguas y escrituras en la Hispania prerromana, ed. F. Villar \& F. Beltrán, Salamanca, pp. 685-718.

VILLAR, F. (2000) - Indoeuropeos y no indoeuropeos en la Hispania prerromana, Salamanca.

VILLAR, F. (2002) - “Los hidrónimos con *up- (*op-) 'agua, río’ en la toponimia prerromana hispana”, Palaeohispanica, 2, pp. 277-291.

Villar, F. \& Pedrero, R. (2001) - "La nueva inscripción lusitana. Arroyo de la Luz III", Religión, lengua y cultura prerromanas de Hispania, ed. F. Villar \& M. P. Fernández Álvarez, Salamanca, pp. 663-698.

Villar, F. \& Prósper, B. M. (2005) - Vascos, celtas e indoeuropeos. Genes y lenguas, Salamanca.

Whatmough, J. (1970) - The dialects of ancient Gaul, Cambridge (Massachusetts). 


\section{EPIGRAPHIC ABBREVIATIONS}

AE - Année Épigraphique

CIL - Corpus Inscriptionum Latinarum

HAEp. - Hispania Antiqua Epigraphica

HEp. - Hispania Epigraphica

ILER - Inscripciones latinas de la España romana, ed. J. Vives (Barcelona, 1971) 
EST. I

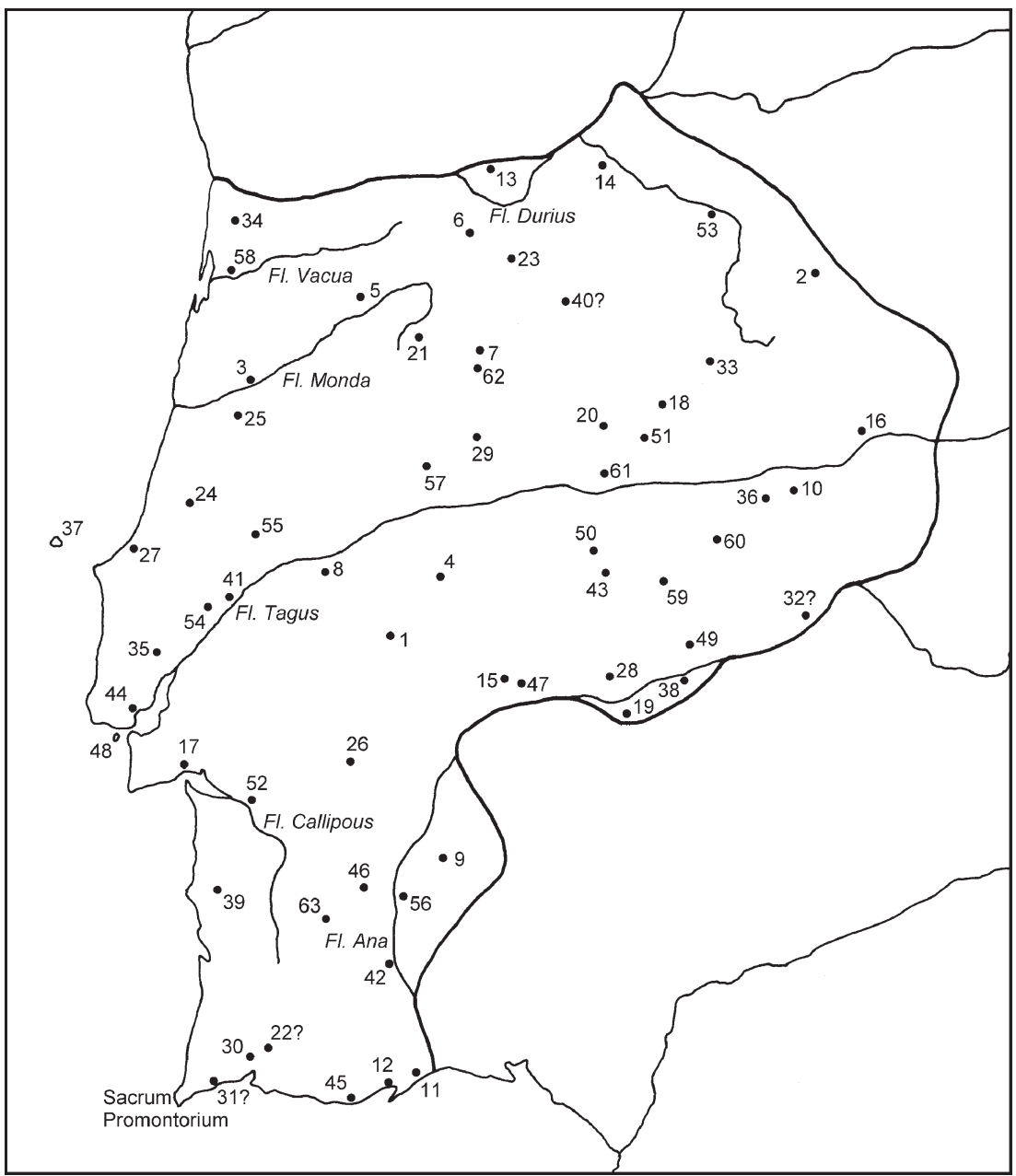

Map of Lusitania locating ancient toponyms

Legend: 1 Abelterion; 2 Abila; 3 Aeminium; 4 Ammaia; 5 Araocelum; 6 Aravi; 7 Arcuce; 8 Aritium; 9 Arucci; 10 Augustobriga; 11 Baesuri; 12 Balsa; 13 Baniensis civitas; 14 Bletisama; 15 Burdua; 16 Caesarobriga; 17 Caetobriga; 18 Capara; 19 Castrum Colubri; 20 Caurium; 21 Centum Cellae; 22 Cilibe; 23 Cobelcorum civitas; 24 Collippo; 25 Conimbriga; 26 Ebora; 27 Eburobrittium; 28 Emerita Augusta; 29 Igaeditani; 30 Ipse; 31 Laccobriga; 32 Lacinimurgi; 33 Lama; 34 Langobriga; 35 Lerabriga; 36 Lomondo; 37 Londobris insula; 38 Metellinum; 39 Mirobriga Celtica; 40 Mirobriga Vettonum; 41 Moron; 42 Myrtilis; 43 Norba; 44 Olisipo; 45 Ossonoba; 46 Pax Iulia; 47 Plagiaria; 48 Poetanium insula; 49 Rodacis; 50 Rouda; 51 Rusticiana; 52 Salacia; 53 Salmantica; 54 Scallabis; 55 Sellium; 56 Serpa; 57 Talabara; 58 Talabriga; 59 Tamusia; 60 Turgalium; 61 Turmulum; 62 Venia; 63 Vipasca. 
EST. II

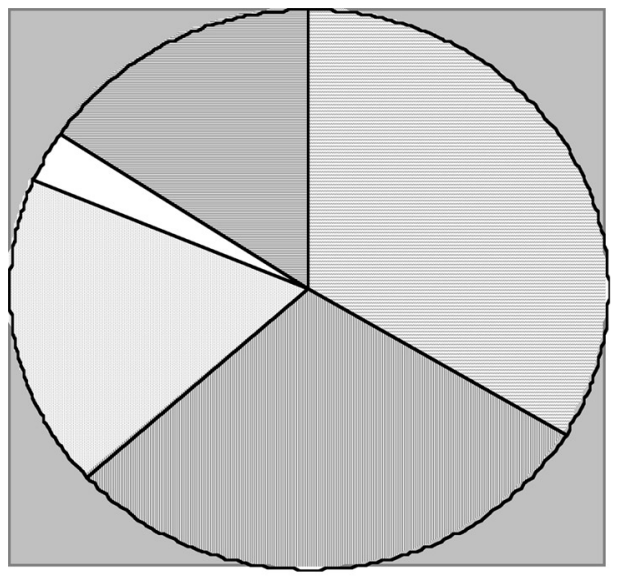

\begin{tabular}{|l|}
\hline$\square$ IE \\
$\square$ Celtic \\
$\square$ Latin \\
$\square$ Other \\
$\square$ Uncertain \\
\hline
\end{tabular}

Chart showing the proportions of Indo-European, Celtic, Latin, and other toponyms in Lusitania 